\title{
UTJECAJ MJERITELJA TE POGREŠAKA PRI IZMJERI NA IZMJERENI PROMJER STABLA
}

\section{INFLUENCE OF A MEASURER AND MEASUREMENT ERRORS ON MEASUREMENT OF A TREE DIAMETER}

\author{
Mario BOŽIĆ ${ }^{1}$, Filip ĐURETA², Ernest GORŠIĆ ${ }^{1}$, Mislav VEDRIŠ1
}

\begin{abstract}
SAŽETAK
U radu je prikazan utjecaj mjeritelja i pogrešaka mjerenja na izmjeru prsnog promjera stabla. Istraživanje je provedeno na nastavno-pokusnom šumskom objektu Zagreb: u nizinskoj sastojini hrasta lužnjaka i običnog graba te u sastojini obične jele i bukve (na nagnutom terenu). Pokušalo se obuhvatiti najčešće pogreške pri izmjeri prsnog promjera te su tri mjeritelja mjerila unakrsne prsne promjere stabala na samoodređenoj i označenoj prsnoj visini. Također, mjeren je promjer na način da je promjerka pozicionirana deset centimetara ispod i iznad stvarne prsne visine, zatim sa krakovima promjerke odmaknutim od debla, s normalnim i jačim pritiskom na krakove te izmjera promjera stabla sa krakovima promjerke okrenutim prema gore radi lakšeg očitanja vrijednosti. Rezultati su pokazali da je razlika između dva unakrsna promjera (eliptičnost stabla) veća nego pogreška izmjere promjera pri subjektivnoj procjeni prsne visine. Također, izmjera provedena ispod i iznad stvarne prsne visine daje statistički značajnu pozitivnu odnosno negativnu vrijednost prsnog promjera u odnosu na stvarnu. Kod krakova odmaknutih od debla dobivene su očekivane niže vrijednosti prsnog promjera kao i kod izmjere sa krakovima okrenutim prema gore. Utvrđene su i razlike u izmjeri promjera između samih mjeritelja. Obzirom da je prsni promjer stabla osnova za procjenu volumena pojedinačnog stabla i sastojine, iz svega spomenutog jasno je da pogreške pri izmjeri prsnog promjera, bile one uzrokovane nepažnjom mjeritelja ili metodološke, mogu imati značajan utjecaj na dobivene rezultate.
\end{abstract}

KLJUČNE RIJEČl: prsni promjer stabla, pogreške mjerenja, odstupanje, izmjera šuma

\section{UVOD}

\section{INTRODUCTION}

Prsni promjer stabla jedna je od osnovnih varijabli pri izmjeri šuma. Najčešće se mjeri promjerkom, pri čemu krakovi moraju biti međusobno paralelni te okomiti na ravnalo. Postupci izmjere opisani su u mnogim udžbenicima izmjere šuma (vidi npr: Loetsch i dr., 1973; Pranjić i Lukić, 1997; Husch i dr., 2003; Banković i Pantić, 2006; Van Laar i Akça, 2007). Prsni promjer dubećih stabala se u Hrvatskoj mjeri na visini $1,30 \mathrm{~m}$ od tla odnosno najviše točke žilišta stabla na nagnutom terenu (pribrežne strane). Promjerka treba pri izmjeri s oba kraka i ravnalom doticati stablo, biti postavljena okomito na uzdužnu os stabla te pritisak na krakove prilikom izmjere treba biti umjeren. Prije same izmjere potrebno je provjeriti je li pomični krak okomit na ravnalo, te po potrebi rektificirati promjerku. Navedena pravila mjeritelji trebaju dobro poznavati te ih se pri izmjeri pridržavati.

Vezano uz spomenutu problematiku Omule (1980) te Kitahara i dr. (2010) istražuju utjecaj utreniranosti mjeritelja (studenata) na kvalitetu izmjere. Važnost utreniranosti stu-

\footnotetext{
1 Prof. dr. sc. Mario Božić, doc. dr. sc. Ernest Goršić, doc. dr. sc. Mislav Vedriš, Zavod za izmjeru i uređivanje šuma, Šumarski fakultet Sveučilišta u Zagrebu, Svetošimunska 25, 10000 Zagreb, Hrvatska; e-mail: bozic@sumfak.hr, egorsic@sumfak.hr, mvedris@sumfak.hr

2 Filip Đureta, univ. bacc. ing. silv., Palih boraca 62, 48316 Đelekovec, Hrvatska; e-mail: filip.djureta@gmail.com
} 
denata Omule promatra kroz činjenicu da agencije za izmjeru često angažiraju studente 3 . godine studija. Johnson i Haag (1985) te Melson i dr. (2002) istražuju pogreške izmjere prsnih promjera pri čemu izmjere provode najprije prije, a potom nakon obilježbe prsne visine. Elzinga i dr. (2005) mjereći opsege stabala dijele pogreške pri izmjeri na: pogreške očitanja ili krivog upisa, pogreške položaja vrpce vezano uz okomicu na uzdužnu os stabla te pogreške visine na kojoj se izmjera provodi (u odnosu na 1,30 m).

$\mathrm{U}$ neposrednom radu sa studentima, ali i kod kolega u praksi, uočeno je nepoštivanje definiranih postupaka izmjere prsnog promjera. Najčešće uočene pogreške su: nepostavljanje promjerke na visinu $1,30 \mathrm{~m}$, nepostavljanje promjerke na definiranu visinu u odnosu na najvišu točku žilišta (s pribrežne strane), izmjera promjera tako da ravnalo ne dotiče stablo („izmjera krakovima“), preveliki pritisak na krakove promjerke te zakretanje krakova prema gore radi lakšeg očitanja na ravnalu promjerke.

Osim toga, poznato je da poprečni presjek stabala više ili manje odstupa od oblika kružnice (vidi npr. Avery i Burkhart, 1983; Husch i dr., 2003), odnosno stabla su manje ili više eliptična. Prema Ugrenoviću (1950) eliptičnost je posljedica asimetričnosti krošnje, koju pak povezuje s nagibom terena i utjecajem vjetra velikog intenziteta i stalnog smjera. Isti autor napominje da su kod hrasta, bukve i jele poprečni presjeci debla više ili manje slični krugu, a da se nepravilnost poprečnog presjeka graba očituje kao užlijebljenost. Da bi se eliminirao utjecaj eliptičnosti na izmjereni promjer pojedinačnog stabla, eliptičnim se stablima uobičajeno mjere dva unakrsna promjera te registrira njihova srednja vrijednost (vidi npr. Loetsch i dr., 1973; Avery i Burkhart, 1983). Na razini uzorka izmjera se najčešće provodi po principu jedno stablo, jedna izmjera, pri čemu se pri izmjerama na kružnim plohama na ravnom terenu pomični krak (vidi npr. Prodan, 1965; Bankovići Pantić, 2006) zakreće prema središtu kruga. Na nagnutim terenima se, u praksi, ravnalo postavlja paralelno sa slojnicom (vidi npr. Prodan, 1965; Banković i Pantić, 2006). Pri izmjeri u nacionalnim inventurama (primjer Švicarske i Hrvatske: Keller, 2005; Čavlović i Božić, 2008) izmjera promjera provodi se zakretanjem ravnala prema središtu plohe, bez obzira na konfiguraciju terena, uz uvjet da je promjerka postavljena na visinu od 1,30 m u odnosu na pribrežnu stranu, ako je teren nagnut. Naprotiv, zanemarivanje eliptičnosti debla pri mjerenju promjera može uzrokovati razlike kod rezultata izmjere, odnosno pogreške.

Cilj ovog rada je kvantificirati te analizirati prethodno navedene pogreške izmjere prsnog promjera na razini stabla odnosno uzorka.

\section{MATERIJAL I METODE MATERIAL AND METHODS}

Svim odabranim stablima mjeren je promjer s korom, s milimetarskom preciznošću, promjerkom Haglőf Mantax, koja je prije samog rada rektificirana. Prije same izmjere mjeritelji su izmjerili visinu $130 \mathrm{~cm}$ od tla na vlastitom tijelu koja je nazvana samoodređenom prsnom visinom.

Izmjeru su provela tri mjeritelja s višegodišnjim iskustvom u izmjerama prema sljedećem redoslijedu:

1. na samoodređenoj prsnoj visini (dva unakrsna promjera (1a, 1b)) - svi mjeritelji,

2. na obilježenoj prsnoj visini (dva unakrsna promjera (2a, 2b)) - svi mjeritelji,

3. $10 \mathrm{~cm}$ ispod (3a), odnosno iznad (3b) obilježene prsne visine - mjeritelj 1 ,

4. na obilježenoj prsnoj visini, ali tako da ravnalo ne dotiče stablo („izmjera krakovima“), s normalnim (4a) te jačim pritiskom na pomični krak promjerke (4b) - mjeritelj 2,

5. na obilježenoj prsnoj visini, pri čemu je ravnalo postavljeno na obilježenu točku, a promjerka zakrenuta krakovima prema gore radi lakšeg očitanja na ravnalu promjerke (5a) - mjeritelj 3 .

Obilježba promjera provedena je nakon što su svi mjeritelji izmjerili promjere na samoodređenoj prsnoj visini (1a i 1b). Mjesto prsne visine (2a) izmjereno je mjernom vrpcom te obilježeno bojom u obliku točke (da ne dođe do oštećenja kore stabla (Loetsch i dr., 1973)).

Izmjera je provedena na dva lokaliteta u sklopu Nastavnopokusnog šumskog objekta Zagreb, Šumarskog fakulteta Sveučilišta u Zagrebu. Izmjere su provedene u nizinskoj šumi hrasta lužnjaka i običnog graba te u gorskoj bukovo-

Tablica 1. Prsni promjeri izmjerenih stabala (cm) po vrstama drveća: Hrast lužnjak (HL), Obični grab (OG), Obična jela (OJ), Obična bukva (OB) Table. 1. Breast height diameter (cm) of measured trees by species: Pedunculate oak (HL), Common hornbeam (OG), Silver fir (OJ), Common beech (OB)

\begin{tabular}{|c|c|c|c|c|c|c|}
\hline $\begin{array}{l}\text { Vrsta drveća } \\
\text { Tree species }\end{array}$ & $\begin{array}{c}\text { Broj stabala } \\
\text { Number of trees }\end{array}$ & $\begin{array}{c}\text { Aritmetička sredina } \\
\text { Mean }\end{array}$ & $\begin{array}{l}\text { Medijan } \\
\text { Median }\end{array}$ & $\begin{array}{l}\text { Minimum } \\
\text { Minimum }\end{array}$ & $\begin{array}{l}\text { Maksimum } \\
\text { Maximum }\end{array}$ & $\begin{array}{l}\text { Standaradna devijacija } \\
\text { Standard deviation }\end{array}$ \\
\hline $\mathrm{HL}$ & 74 & 61,1 & 61,8 & 31,4 & 101,3 & 16,2 \\
\hline OG & 56 & 30,5 & 30,2 & 11,5 & 53,2 & 11,6 \\
\hline $0 \mathrm{~J}$ & 76 & 44,9 & 47,8 & 11,7 & 90,5 & 21,8 \\
\hline OB & 76 & 37,5 & 37,6 & 11,7 & 72,2 & 16,3 \\
\hline Ukupno Total & 282 & 44,3 & 42,7 & 11,5 & 101,3 & 20,4 \\
\hline
\end{tabular}


jelovoj šumi. Mjerena su stabla koja pripadaju najzastupljenijim vrstama drveća u Hrvatskoj: hrast lužnjak, obični grab, obična jela i obična bukva. Ukupno su izmjerena 282 stabla: 74 stabla hrasta lužnjaka, 56 stabala običnog graba, te po 76 stabala obične jele i obične bukve (ukupno 4794 izmjerena promjera). Pri odabiru stabala vodilo se računa da se obuhvati cijeli raspon promjera za svaku vrstu drveća (Tablica 1).

Mjerna se grupa sastojala od 2 člana, od kojih je jedan mjerio, a drugi u terenske obrasce upisivao podatke izmjere. Prije same izmjere, mjeriteljima je uz pomoć mjerne vrpce na tijelu izmjerena visina od $1,30 \mathrm{~m}$. Visina mjeritelja može utjecati na visinu postavljanja promjerke pri samoodređivanju prsne visine, a u ovom istraživanju iznosila je: $1,75 \mathrm{~m}$ (mjeritelj 1), 1,73 m (mjeritelj 2), 1,89 m (mjeritelj 3).

Promjeri 1a, 2a, 3a, 3b, 4a, 4b i 5a su u nizinskom području (šuma hrasta lužnjaka i običnog graba) mjereni postavljanjem ravnala promjerke paralelno s pravcem kretanja $\left(32^{\circ}\right)$, a u gorskom području (šuma bukve i jele) „, slojnici”, pri čemu se prsna visina određivala i izmjera provodila s pribrežne strane.

U uredu su podatci iz terenskih obrazaca prepisani, provedena je njihova provjera te ispravak krivo unesenih podataka.

Podatci su analizirani t-testom zavisnih varijabli (razlike položaja promjerke), analizom varijance ponovljenih mje- renja sa Scheffeovim post hoc testom (razlike između mjeritelja) te linearnom regresijskom analizom (povezanost razlika izmjere i promjera stabala) uz razinu značajnosti 0,05 u programskom paketu Statistica 13.3 (TIBCO Software Inc., 2018).

\section{REZULTATI ISTRAŽIVANJA RESULTS}

Rezultati su iskazani tablično, kao razlika srednjih vrijednosti uzorka uz iskaz njihove značajnosti, te slikovno kao rasponi odstupanja izmjera pojedinačnih stabala odnosno utjecaja promjera stabala na veličinu odstupanja.

\section{Razlike položaja promjerke pri izmjeri - Differences in caliper position during measurement}

U ovom segmentu istraživanja najprije su prikazane razlike između izmjera koje su proveli svi mjeritelji: Unakrsnih promjera (1a-1b; 2a-2b) te točnosti samoodređivanja prsne visine (1a-2a). Navedene razlike i rezultati t-testa zavisnih varijabli prikazane su u Tablicama 2-4 te na Slikama 1 i 2 .

Razlike između dvaju unakrsnih promjera na razini cijelog uzorka za pojedinu vrstu drveća veće su i statistički značajne kod graba i bukve. Kod lužnjaka i jele one su manje te nisu statistički značajne (Tablice 2 i 3 ).

Tablica 2. Prosječne razlike unakrsnih promjera na samoodređenoj prsnoj visini (1a-1b) i statistička značajnost razlika ( $p$ vrijednost) po vrstama drveća i mjeriteljima

Table 2. Average differences between two crosswise diameters at self-estimated breast height (1a-1b) and statistical difference (p value) by tree species and measurers

\begin{tabular}{|c|c|c|c|c|c|c|c|c|}
\hline \multirow{2}{*}{$\begin{array}{l}\text { Mjeritelj } \\
\text { Measurer }\end{array}$} & \multicolumn{2}{|c|}{$\begin{array}{c}\text { Hrast lužnjak } \\
\text { Pedunculate oak }\end{array}$} & \multicolumn{2}{|c|}{$\begin{array}{c}\text { Obični grab } \\
\text { Common hornbeam }\end{array}$} & \multicolumn{2}{|c|}{$\begin{array}{l}\text { Obična jela } \\
\text { Silver fir }\end{array}$} & \multicolumn{2}{|c|}{$\begin{array}{l}\text { Obična bukva } \\
\text { Common beech }\end{array}$} \\
\hline & $1 \mathrm{a}-1 \mathrm{~b}, \mathrm{~cm}$ & $\mathrm{p}$ & $1 \mathrm{a}-1 \mathrm{~b}, \mathrm{~cm}$ & $\mathrm{p}$ & $1 \mathrm{a}-1 \mathrm{~b}, \mathrm{~cm}$ & $\mathrm{p}$ & $1 a-1 b, c m$ & $\mathrm{p}$ \\
\hline 1 & 0,33 & 0,3600 & 0,95 & 0,0203 & $-0,22$ & 0,4044 & $-1,70$ & $<0,0001$ \\
\hline 2 & 0,25 & 0,5285 & 1,09 & 0,0057 & $-0,05$ & 0,8672 & $-1,79$ & $<0,0001$ \\
\hline 3 & 0,18 & 0,6510 & 0,99 & 0,0097 & $-0,07$ & 0,8133 & $-1,73$ & $<0,0001$ \\
\hline Prosječno - Average & 0,26 & 0,4897 & 1,01 & 0,0080 & $-0,12$ & 0,6645 & $-1,74$ & $<0,0001$ \\
\hline
\end{tabular}

Tablica 3. Prosječne razlike unakrsnih promjera na obilježenoj prsnoj visini (2a-2b) i statistička značajnost razlika (p vrijednost) po vrstama drveća i mjeriteljima

Table 3. Average differences between two crosswise diameters at marked breast height ( $2 \mathrm{a}-2 \mathrm{~b})$ and statistical difference ( $\mathrm{p}$ value) by tree species and measurers

\begin{tabular}{|c|c|c|c|c|c|c|c|c|}
\hline \multirow{2}{*}{$\begin{array}{l}\text { Mjeritelj } \\
\text { Measurer }\end{array}$} & \multicolumn{2}{|c|}{$\begin{array}{c}\text { Hrast lužnjak } \\
\text { Pedunculate oak }\end{array}$} & \multicolumn{2}{|c|}{$\begin{array}{c}\text { Obični grab } \\
\text { Common hornbeam }\end{array}$} & \multicolumn{2}{|c|}{$\begin{array}{l}\text { Obična jela } \\
\text { Silver fir }\end{array}$} & \multicolumn{2}{|c|}{$\begin{array}{l}\text { Obična bukva } \\
\text { Common beech }\end{array}$} \\
\hline & $2 a-2 b, c m$ & $\mathrm{p}$ & $2 a-2 b, c m$ & $\mathrm{p}$ & $2 a-2 b, c m$ & $\mathrm{p}$ & $2 a-2 b, c m$ & $\mathrm{p}$ \\
\hline 1 & 0,33 & 0,3954 & 1,34 & 0,0010 & 0,16 & 0,6294 & $-1,80$ & $<0,0001$ \\
\hline 2 & 0,29 & 0,4661 & 1,56 & 0,0004 & 0,10 & 0,7436 & $-1,80$ & $<0,0001$ \\
\hline 3 & 0,71 & 0,0871 & 1,49 & 0,0003 & 0,23 & 0,4775 & $-1,62$ & $<0,0001$ \\
\hline Average - Prosječno & 0,44 & 0,2553 & 1,46 & 0,0004 & 0,16 & 0,6044 & $-1,78$ & $<0,0001$ \\
\hline
\end{tabular}


Tablica 4. Prosječne razlike promjera na samoodređenoj i obilježenoj prsnoj visini (1a-2a) i statistička značajnost razlika (p vrijednost) po vrstama drveća i mjeriteljima

Table 4. Average diameter differences between self-estimated and marked breast height (1a-2a) and statistical difference ( $p$ value) by tree species and measurers

\begin{tabular}{|c|c|c|c|c|c|c|c|c|}
\hline \multirow{2}{*}{$\begin{array}{l}\text { Mjeritelj } \\
\text { Measurer }\end{array}$} & \multicolumn{2}{|c|}{$\begin{array}{c}\text { Hrast lužnjak } \\
\text { Pedunculate oak }\end{array}$} & \multicolumn{2}{|c|}{$\begin{array}{c}\text { Obični grab } \\
\text { Common hornbeam }\end{array}$} & \multicolumn{2}{|c|}{$\begin{array}{c}\text { Obična jela } \\
\text { Silver fir }\end{array}$} & \multicolumn{2}{|c|}{$\begin{array}{l}\text { Obična bukva } \\
\text { Common beech }\end{array}$} \\
\hline & $1 \mathrm{a}-2 \mathrm{a}, \mathrm{cm}$ & $p$ & $1 \mathrm{a}-2 \mathrm{a}, \mathrm{cm}$ & $\mathrm{p}$ & $1 \mathrm{a}-2 \mathrm{a}, \mathrm{cm}$ & $\mathrm{p}$ & $1 \mathrm{a}-2 \mathrm{a}, \mathrm{cm}$ & $\mathrm{p}$ \\
\hline 1 & $-0,22$ & 0,0292 & $-0,20$ & 0,2809 & $-0,59$ & 0,0008 & $-0,32$ & 0,0024 \\
\hline 2 & $-0,11$ & 0,3870 & $-0,18$ & 0,2108 & $-0,003$ & 0,9773 & $-0,08$ & 0,3435 \\
\hline 3 & $-0,37$ & 0,0004 & $-0,18$ & 0,3196 & 0,08 & 0,5581 & $-0,02$ & 0,8180 \\
\hline Prosječno - Average & $-0,23$ & 0,0106 & $-0,18$ & 0,2092 & $-0,17$ & 0,1088 & $-0,14$ & 0,0420 \\
\hline
\end{tabular}
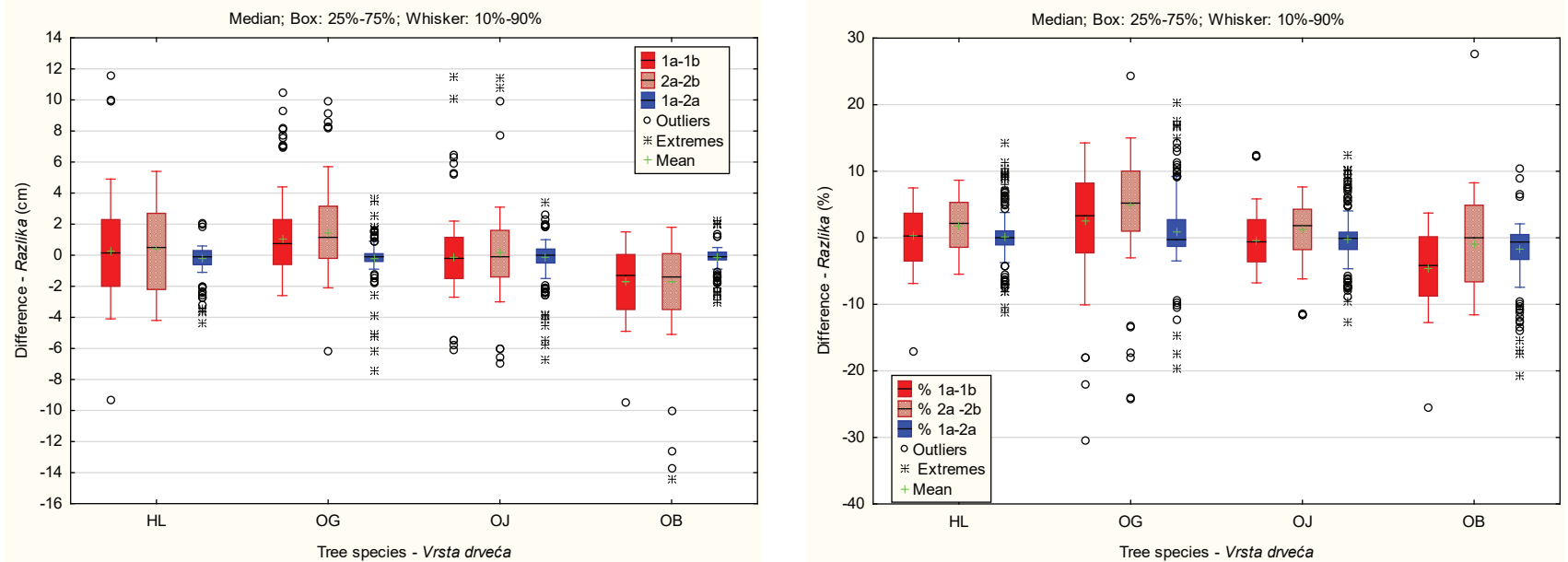

Slika 1. Razlike unakrsnih promjera na samoodređenoj visini (1a-1b), obilježenoj visini (2a-2b) te između promjera na samoodređenoj i obilježenoj visini (1a-2a), za hrast lužnjak (HL), obični grab (OG), običnu jelu (OJ) te običnu bukvu (OB); u cm (slika lijevo) te u \% (slika desno)

Figure 1. Differences between crosswise diameters at self-estimated breast height (1a-1b), marked beast height (2a-2b) and between diameters at selfestimated and marked beast height (1a-2a), for Pedunculate oak (HL), Common hornbeam (OG), Silver fir (OJ) and Common beech (OB); in cm (figure left) and in \% (figure right)

Iz rezultata prikazanih u Tablici 4 vidljivo je da najmanju razliku između izmjere promjera na samoodređenoj i obilježenoj prsnoj visini ima mjeritelj 2 , a najveću i većim dijelom statistički značajnu razliku mjeritelj 1.

Rezultati prikazani na slici 1 ukazuju da se razlike unakrsnih promjera pojedinačnih stabala nalaze najvećim dijelom u rasponu $\pm 2-3 \mathrm{~cm}$ ili $\pm 3-8 \%$ (50\% razlika) odnosno $\pm 3-5 \mathrm{~cm}$ ili $\pm 8-15 \%$ ( $80 \%$ razlika). Razlika između unakrsnih promjera kod pojedinih stabala su i do $15 \mathrm{~cm}$ odnosno 30 -ak \%.

Razlike između promjera izmjerenog na samoodređenoj visini i obilježenoj visini značajno su manje od razlika dvaju unakrsnih promjera.

Kako je vidljivo iz Slike 1, razlike između unakrsnih promjera su pozitivne i negativne, sa srednjim odstupanjima koja su prikazana na slici te u Tablicama 2-4. Budući da redoslijed unakrsnih promjera nije bitan, kao jasniji pokazatelj eliptičnosti stabala na Slici 2 prikazana su apsolutna odstupanja unakrsnih promjera.

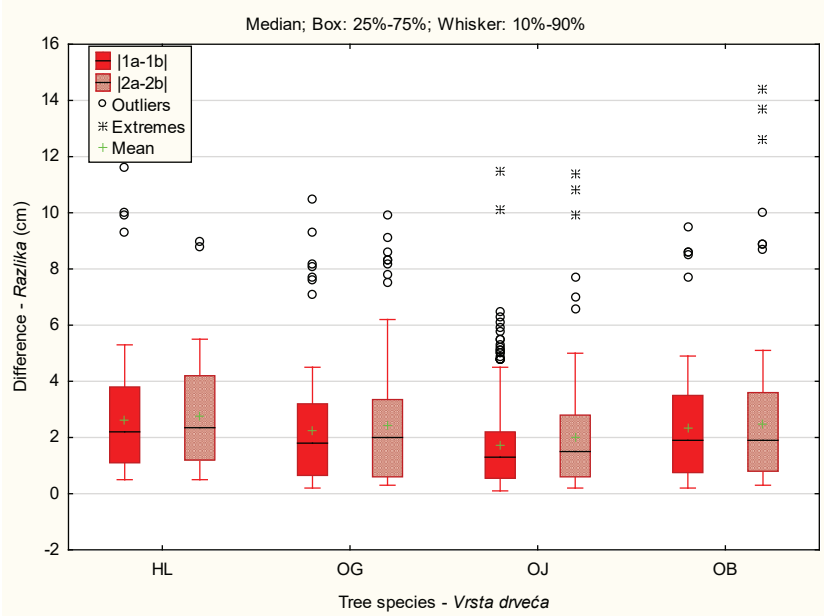

Slika 2. Apsolutni iznosi razlika unakrsnih promjera na samoodređenoj visini (1a-1b) te na obilježenoj visini (2a-2b), za hrast lužnjak (HL), obični grab (OG), običnu jelu (OJ) te običnu bukvu (OB)

Figure 2. Absolute differences between crosswise diameters at self-estimated breast height (1a-1b) and at marked height (2a-2b), for Pedunculate oak (HL), Common hornbeam (OG), Silver fir (OJ) and European beech (OB) 


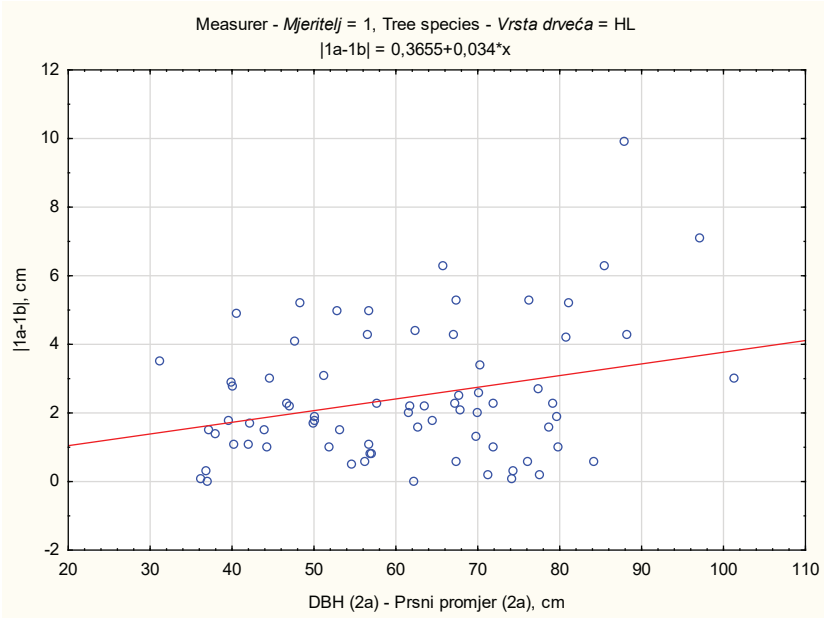

Slika 3. Apsolutne razlike unakrsnih promjera (1a-1b) u ovisnosti o prsnom promjeru stabla za hrast lužnjak

Figure 3. Absolute differences between crosswise diameters (1a-1b) in relation to breast height diameter for Pedunculate oak
Iz Slike 2 vidljivo je da gotovo nema stabla koje nije barem malo eliptično. Srednje apsolutno odstupanje unakrsnih promjera (eliptičnost) najmanje je kod jele $(1,5-2 \mathrm{~cm})$, a kod ostalih vrsta iznosi $2-3 \mathrm{~cm}$.

Zbog utvrđivanja utjecaja promjera stabla na razlike između unakrsnih promjera (eliptičnost) te promjera izmjerenih na samoodređenoj i označenoj prsnoj visini provedena je linearna regresijska analiza. Kao primjer prikazana je apsolutna razlika između unakrsnih promjera na samoodređenoj prsnoj visini (Slika 3) za hrast lužnjak, mjeritelja 1.

Iz Slike 3 vidljivo je da se apsolutna razlika između unakrsnih promjera izmjerenih na samoodređenoj prsnoj visini (1a-1b) povećava povećanjem promjera stabla, uz dosta veliko rasipanje podataka. Slično vrijedi i za ostale izmjere istih mjeritelja (2a-2b; 1a-2a; 3a-2a; 3b-2a, 4a-2a; 4b-2a i 5a-2a), kao i razlike između mjeritelja (za izmjere koje su provodila sva trojica).

Tablica 5. Prosječne razlike promjera mjerenih $10 \mathrm{~cm}$ ispod i na obilježenoj prsnoj visini (3a-2a) te statistička značajnost razlika ( $p$ vrijednost) po vrstama drveća

Table 5. Average differences of diameters measured $10 \mathrm{~cm}$ under and at marked breast height (3a-2a) and statistical difference ( $p$ value) by tree species

\begin{tabular}{|c|c|c|c|c|c|c|c|c|}
\hline \multirow{2}{*}{$\begin{array}{l}\text { Mjeritelj } \\
\text { Measurer }\end{array}$} & \multicolumn{2}{|c|}{$\begin{array}{c}\text { Hrast lužnjak } \\
\text { Pedunculate oak }\end{array}$} & \multicolumn{2}{|c|}{$\begin{array}{c}\text { Obični grab } \\
\text { Common hornbeam }\end{array}$} & \multicolumn{2}{|c|}{$\begin{array}{l}\text { Obična jela } \\
\text { Silver fir }\end{array}$} & \multicolumn{2}{|c|}{$\begin{array}{l}\text { Obična bukva } \\
\text { Common beech }\end{array}$} \\
\hline & $3 a-2 a, c m$ & $p$ & $3 a-2 a, c m$ & $\mathrm{p}$ & $3 a-2 a, c m$ & $p$ & $3 a-2 a, c m$ & $p$ \\
\hline 1 & 0,80 & $<0,0001$ & 0,35 & 0,0191 & 0,49 & $<0,0001$ & 0,23 & $<0,0001$ \\
\hline
\end{tabular}

Tablica 6. Prosječne razlike promjera mjerenih $10 \mathrm{~cm}$ iznad i na obilježenoj prsnoj visini (3b-2a) te statistička značajnost razlika ( $p$ vrijednost) po vrstama drveća

Table 6. Average differences of diameters measured $10 \mathrm{~cm}$ over and at marked breast height (3b-2a) and statistical difference (p value) by tree species

\begin{tabular}{cccccccccc} 
Mjeritelj & \multicolumn{2}{c}{$\begin{array}{c}\text { Hrast lužnjak } \\
\text { Pedunculate oak }\end{array}$} & \multicolumn{2}{c}{$\begin{array}{c}\text { Obični grab } \\
\text { Common hornbeam }\end{array}$} & \multicolumn{2}{c}{$\begin{array}{c}\text { Obična jela } \\
\text { Silver fir }\end{array}$} & \multicolumn{2}{c}{$\begin{array}{c}\text { Obična bukva } \\
\text { Common beech }\end{array}$} \\
Measurer & $3 \mathrm{~b}-2 \mathrm{a}, \mathrm{cm}$ & $\mathrm{p}$ & $3 \mathrm{~b}-2 \mathrm{a}, \mathrm{cm}$ & $\mathrm{p}$ & $3 \mathrm{~b}-2 \mathrm{a}, \mathrm{cm}$ & $\mathrm{p}$ & $3 \mathrm{~b}-2 \mathrm{a}, \mathrm{cm}$ & $\mathrm{pm}$ \\
\hline 1 & $-0,60$ & $<0,0001$ & $-0,21$ & 0,0832 & $-0,40$ & $<0,0001$ & $-0,22$ & 0,0002 \\
\hline
\end{tabular}

Tablica 7. Prosječne razlike promjera mjerenih tako da ravnalo ne dotiče stablo, s normalnim pritiskom krakova (4a) i na obilježenoj prsnoj visini (2a) te statistička značajnost razlika ( $p$ vrijednost) po vrstama drveća

Table 7. Average differences of diameters measured with caliper beam held apart from the tree with normal pressure applied on caliper arms (4a) and at marked breast height (2a) with statistical significance of differences ( $p$ value) by tree species

\begin{tabular}{|c|c|c|c|c|c|c|c|c|}
\hline \multirow{2}{*}{$\begin{array}{l}\text { Mjeritelj } \\
\text { Measurer }\end{array}$} & \multicolumn{2}{|c|}{$\begin{array}{c}\text { Hrast lužnjak } \\
\text { Pedunculate oak }\end{array}$} & \multicolumn{2}{|c|}{$\begin{array}{c}\text { Obični grab } \\
\text { Common hornbeam }\end{array}$} & \multicolumn{2}{|c|}{$\begin{array}{l}\text { Obična jela } \\
\text { Silver fir }\end{array}$} & \multicolumn{2}{|c|}{$\begin{array}{l}\text { Obična bukva } \\
\text { Common beech }\end{array}$} \\
\hline & $4 a-2 a, c m$ & $p$ & $4 a-2 a, c m$ & $p$ & $4 a-2 a, c m$ & $p$ & $4 a-2 a, c m$ & $p$ \\
\hline 2 & $-0,26$ & $<0,0001$ & $-0,13$ & 0,0029 & $-0,17$ & $<0,0001$ & $-0,21$ & $<0,0001$ \\
\hline
\end{tabular}

Tablica 8. Prosječne razlike promjera mjerenih tako da ravnalo ne dotiče stablo, s jačim pritiskom krakova (4b) i na obilježenoj prsnoj visini (2a) te statistička značajnost razlika (p vrijednost) po vrstama drveća

Table 8. Average differences of diameters measured with caliper beam held apart from the tree with higher pressure applied on caliper arms (4b) and at marked breast height (2a) with statistical significance of differences ( $p$ value) by tree species

\begin{tabular}{ccccccccc} 
Mjeritelj & \multicolumn{2}{c}{$\begin{array}{c}\text { Hrast lužnjak } \\
\text { Pedunculate oak }\end{array}$} & \multicolumn{2}{c}{$\begin{array}{c}\text { Obični grab } \\
\text { Common hornbeam }\end{array}$} & \multicolumn{2}{c}{$\begin{array}{c}\text { Obična jela } \\
\text { Silver fir }\end{array}$} & \multicolumn{2}{c}{$\begin{array}{c}\text { Obična bukva } \\
\text { Common beech }\end{array}$} \\
Measurer & 4b-2a, cm & $p$ & $4 b-2 a, c m$ & $p$ & $4 b-2 a, c m$ & $p$ & $4 b-2 a, c m$ & $p$ \\
2 & $-1,24$ & $<0,0001$ & $-0,83$ & $<0,0001$ & $-0,64$ & $<0,0001$ & $-0,63$ & $<0,0001$
\end{tabular}


Tablica 9. Prosječne razlike promjera mjerenih s krakovima zakrenutima gore (5a) i na obilježenoj prsnoj visini (2a) te statistička značajnost razlika (p vrijednost) po vrstama drveća

Table 9. Average differences of diameters measured with caliper arms turned up (5a) and at marked breast height (2a) with statistical significance of differences ( $p$ value) by tree species

\begin{tabular}{ccccccccc} 
Mjeritelj & \multicolumn{2}{c}{$\begin{array}{c}\text { Hrast lužnjak } \\
\text { Pedunculate oak }\end{array}$} & \multicolumn{2}{c}{$\begin{array}{c}\text { Obični grab } \\
\text { Common hornbeam }\end{array}$} & \multicolumn{2}{c}{$\begin{array}{c}\text { Obična jela } \\
\text { Silver fir }\end{array}$} & \multicolumn{2}{c}{$\begin{array}{c}\text { Obična bukva } \\
\text { Common beech }\end{array}$} \\
Measurer & $5 \mathrm{a}-2 \mathrm{a}, \mathrm{cm}$ & $\mathrm{p}$ & $5 \mathrm{a}-2 \mathrm{a}, \mathrm{cm}$ & $\mathrm{p}$ & $5 \mathrm{a}-2 \mathrm{a}, \mathrm{cm}$ & $\mathrm{p}$ & $5 \mathrm{a}-2 \mathrm{a}, \mathrm{cm}$ & $\mathrm{pm}$ \\
\hline 3 & $-0,79$ & $<0,0001$ & $-0,24$ & 0,0023 & $-0,43$ & $<0,0001$ & $-0,25$ & $<0,0001$ \\
\hline
\end{tabular}

Srednja odstupanja promjera mjerenih 10 -ak $\mathrm{cm}$ ispod ili iznad prsne visine u odnosu na promjere izmjerene na obilježenom mjestu (3a-2a; 3b-2a) prikazana su u Tablicama 5 i 6 , a raspon odstupanja svih stabala na slici 4 . Srednja
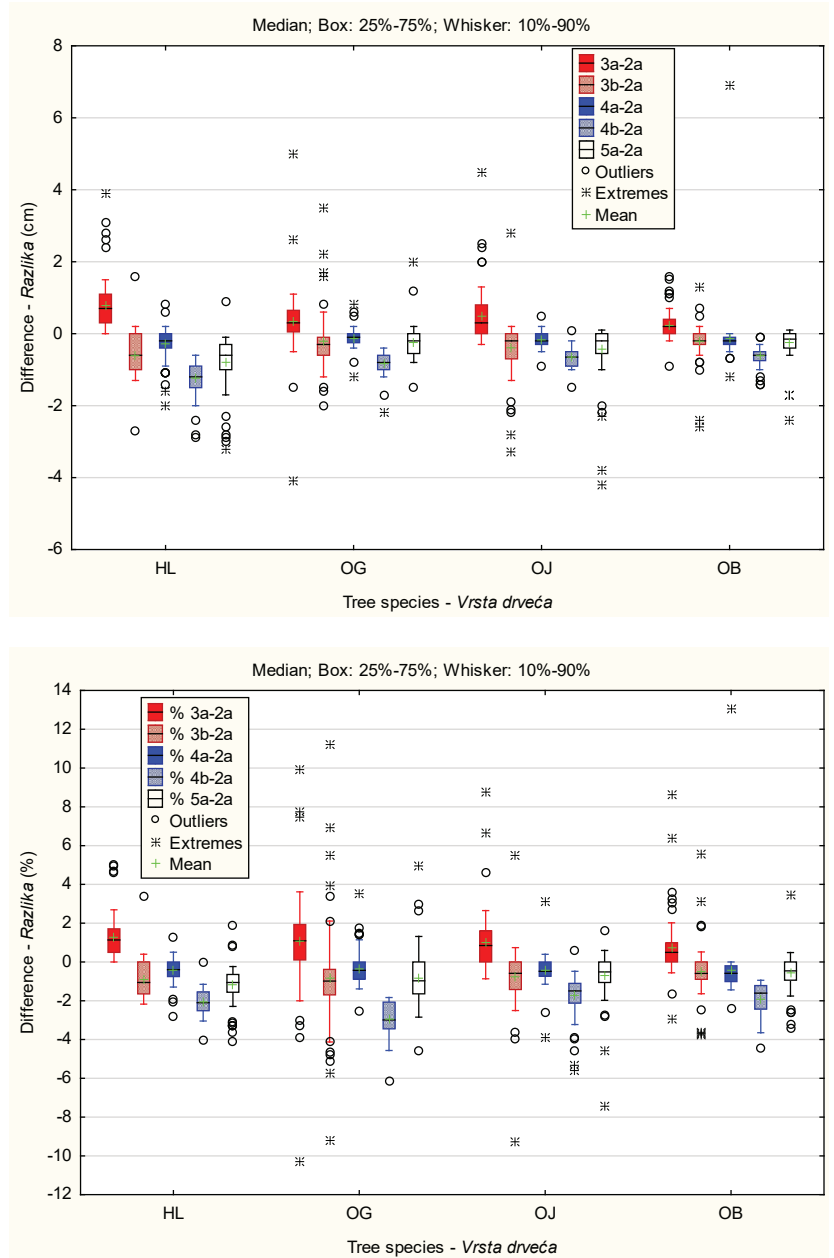

Slika 4. Razlike promjera mjerenih $10 \mathrm{~cm}$ ispod prsne visine (3a), 10 $\mathrm{cm}$ iznad prsne visine (3b), s odmaknutim ravnalom i normalnim pritiskom krakova (4a), s odmaknutim ravnalom i jačim pritiskom krakova (4b) te zakrenutih krakova gore (5a) u odnosu na obilježeni promjer (2a), za hrast lužnjak (HL), obični grab (OG), običnu jelu (OJ) te običnu bukvu (OB); u cm (slika gore) te u \% (slika dolje)

Figure 4. Differences between diameters measured $10 \mathrm{~cm}$ under breast height (3a), $10 \mathrm{~cm}$ above breast height (3b), with caliper beam held apart from the tree and normal pressure on caliper arms (4a), with with caliper beam held apart from the tree and higher pressure on caliper arms (4b), and arms turned up (5a) in relation to marked breast height diameter (2a), for Pedunculate oak (HL), Common hornbeam (OG), Silver fir (OJ) and Common beech (OB), in cm (figure above) and in \% (figure under) odstupanja promjera kada ravnalo pri izmjeri nije doticalo deblo („izmjera krakovima“) s normalnim te jačim pritiskom na pomični krak promjerke, u odnosu na promjere izmjerene na obilježenom mjestu (4a-2a; 4b-2a) prikazana su u Tablicama 7 i 8 , a raspon odstupanja svih stabala na slici 4. Srednja odstupanja promjera kod kojih su krakovi promjerke zakretani prema gore radi lakšeg očitanja na ravnalu promjerke u odnosu na promjere izmjerene na obilježenom mjestu (5a-2a) prikazana su u Tablici 9, a raspon odstupanja svih stabala na slici 4 .

Iz rezultata prikazanih u Tablicama 5 i 6 vidljivo je da srednje vrijednosti razlika promjera mjerenih na visini $1,20 \mathrm{~m}$ u odnosu na prsnu visinu očekivano imaju pozitivan predznak, a razlika promjera mjerenih na visini $1,40 \mathrm{~m} \mathrm{u}$ odnosu na prsni promjer očekivano imaju negativan predznak. Te su razlike statistički značajne, osim kod običnog graba (razlike između izmjere na visini 1,40 u odnosu na $1,30 \mathrm{~m}$ ). Razlika je najveća kod hrasta lužnjaka. Veća je razlika između izmjere na 1,20 i 1,30 m u odnosu na razliku izmjere na 1,40 i 1,30 m, osim kod obične bukve kod koje je podjednaka.

Iz Slike 4 vidljivo je da se razlike između promjera izmjerenih više i niže od prsne visine nalaze većim dijelom $u$ rasponu do $1,5 \mathrm{~cm}$ odnosno $2 \%$. Pojedina stabla odstupaju i do 3-5 cm, maksimalno 10-14\%. Svakako valja zamijetiti da su pojedina stabla deblja na prsnoj nego na visini od $1,20 \mathrm{~m}$, odnosno na visini od $1,40 \mathrm{~m}$ u odnosu na prsnu visinu, što je posebno izraženo kod običnoga graba.

Iz rezultata prikazanih u Tablicama 7 i 8 vidljivo je da srednje vrijednosti razlika promjera mjerenog tako da ravnalo pri izmjeri ne dotiče stablo („izmjera krakovima“), s normalnim te jačim pritiskom na pomični krak promjerke u odnosu na promjere izmjerene na obilježenom mjestu, očekivano imaju negativan predznak, pri čemu su razlike očekivano veće kod jačeg pritiska na pomični krak pri izmjeri. Razlike su uz normalni pritisak na pomični krak najveće kod lužnjaka te bukve, a uz jači pritisak na pomični krak kod lužnjaka i graba. Kod svih vrsta te razlike su statistički značajne.

Iz Slike 4 vidljivo je da se razlike između promjera izmjerenih tako da ravnalo pri izmjeri ne dotiče stablo („izmjera krakovima") u odnosu na promjere izmjerene na obilježe- 
nom mjestu, nalaze većim dijelom u rasponu -1 do $+0,5$ $\mathrm{cm}$ odnosno $\pm 1 \%$, uz pojedina odstupanja koja se nalaze u rasponu -2 do $+1 \mathrm{~cm}$ odnosno $\pm 4 \%$, uz normalni pritisak na pomični krak, odnosno većim dijelom od $-0,5$ do $-2 \mathrm{~cm}$ odnosno -1 do $-5 \%$, uz pojedina odstupanja u rasponu $-3 \mathrm{~cm}$ odnosno $-6 \%$, kod jačeg pritiska na pomični krak promjerke.

Iz rezultata prikazanih u Tablici 9 vidljivo je da srednje vrijednosti razlika promjera mjerenog tako da su krakovi promjerke zakretani prema gore radi lakšeg očitanja na ravnalu promjerke u odnosu na promjere izmjerene na obilježenom mjestu, očekivano imaju negativan predznak. Razlike su statistički značajne kod svih vrsta, a najveće su kod lužnjaka i jele.

Iz Slike 4 vidljivo je da se razlike između promjera izmjerenih tako da su krakovi promjerke zakretani prema gore radi lakšeg očitanja na ravnalu promjerke u odnosu na promjere izmjerene na obilježenom mjestu nalaze većim dijelom u rasponu $-1,5$ do $+0,5 \mathrm{~cm}$ odnosno od-2,5 do $1,5 \%$, uz pojedina odstupanja koja se nalaze u rasponu -4 do $+2 \mathrm{~cm}$ odnosno -4 do $+5 \%$.

\section{Razlike između mjeritelja - Differences between measurers}

Razlike između mjeritelja promatrane su za izmjere na samoodređenoj visini (1a) te za oba unakrsna promjera na obilježenoj prsnoj visini (2a i 2b). Preliminarnom analizom izmjere unakrsnih promjera kod tri stabla obične bukve uočene su ekstremne razlike. Dodatnom provjerom uočeno je da je promjer $2 \mathrm{~b}$ kod jednog stabla pogrešno upisan $(21,1$ umjesto $12,1 \mathrm{~cm}$ ) te je to naknadno ispravljeno. Kod ostala dva stabla razlike su $14,4 \mathrm{~cm}$ i $6,9 \mathrm{~cm}$, a podatci su točno prepisani s terenskih obrazaca, pa se vjerojatno radi o pogrešnom upisu pri izmjeri.

Rezultati razlika između mjeritelja su prikazani u Tablicama 10-12 te na Slikama 5-7.

Iz Tablice 10 vidljivo je da su razlike između mjeritelja kod samoodređivanja prsne visine, veće te većim dijelom statistički značajne između mjeritelja 1 i ostala dva mjeritelja za
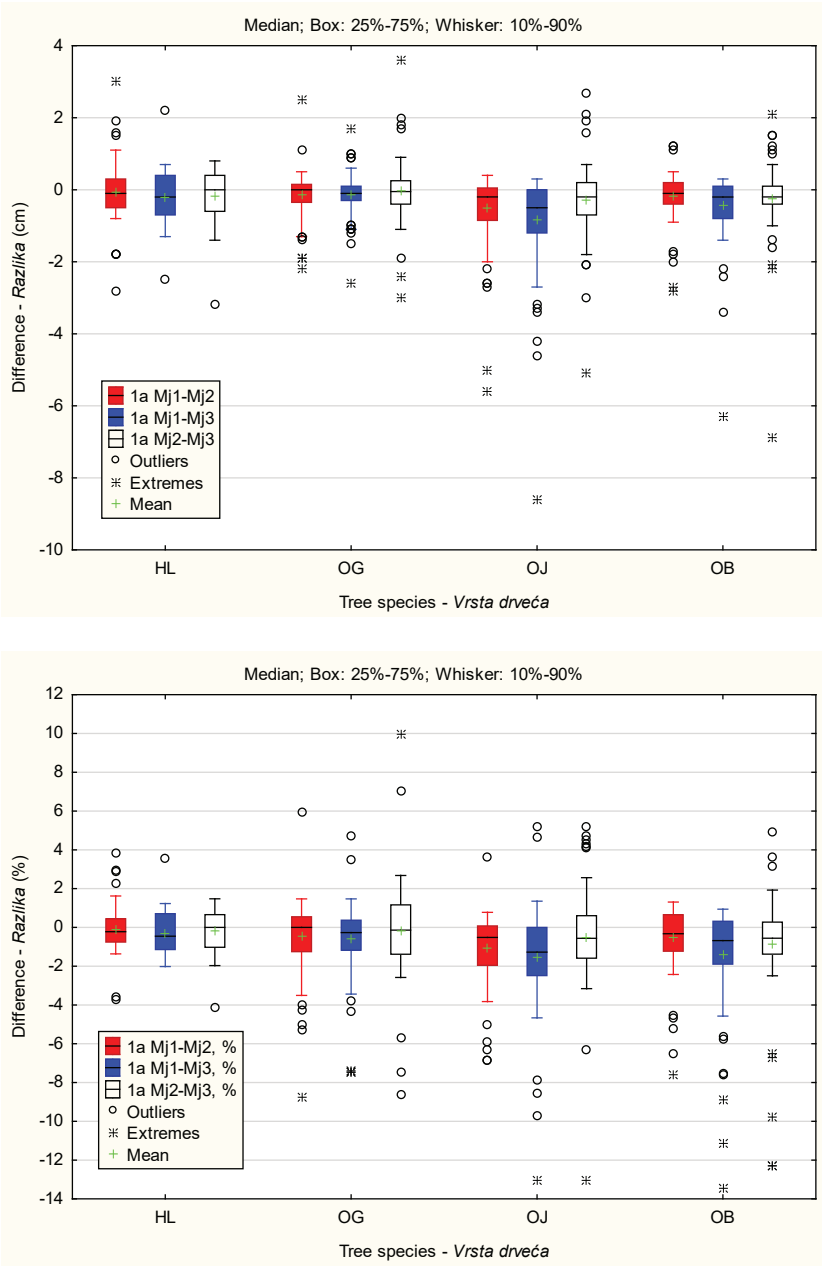

Slika 5. Razlike promjera na samoodređenoj visini (1a) između mjeritelja, za hrast lužnjak (HL), obični grab (OG), običnu jelu (OJ) te običnu bukvu (OB); u cm (slika gore) te u \% (slika dolje)

Figure 5. Differences in diameters on self defined breast height (1a) between measurers, for pedunculate oak (HL), common hornbeam (OG), silver fir (OJ) and European beech (OB): in cm (figure above) and in \% (figure under)

izmjeru provedenu na nagnutom terenu (jela i bukva), gdje je mjeritelj 1 u prosjeku mjerio manje promjere. Veći dio razlika promjera između mjeritelja nalazi se u rasponu $\pm 1,5$ $\mathrm{cm}$ odnosno $2 \%$. U ekstremnim slučajevima razlike su i do $9 \mathrm{~cm}$ odnosno 14\% (Slika 5).

Tablica 10. Prosječne razlike promjera na samoodređenoj visini (1a) između mjeritelja (u cm), rezultati ANOVA-e ponovljenih mjerenja (F i p), te post hoc testa između pojedinih mjeritelja (p vrijednost)

Table 10. Average differences in diameters on self defined breast height (1a) between measurers (in $\mathrm{cm}$ ), results of ANOVA with repeated measurements ( $F$ and $p)$, and post hoc test between individual measurers ( $p$ value)

\begin{tabular}{|c|c|c|c|c|c|c|c|c|}
\hline Mjeritelj & \multicolumn{2}{|c|}{$\begin{array}{c}\text { Hrast lužnjak } \\
\text { Pedunculate oak }\end{array}$} & \multicolumn{2}{|c|}{ Obični grab Common hornbeam } & \multicolumn{2}{|c|}{$\begin{array}{l}\text { Obična jela } \\
\text { Silver fir }\end{array}$} & \multicolumn{2}{|c|}{ Obična bukva Common beech } \\
\hline Measurer & $1 \mathrm{a}, \mathrm{cm}$ & $\mathrm{p}$ & $1 \mathrm{a}, \mathrm{cm}$ & $\mathrm{p}$ & $1 \mathrm{a}, \mathrm{cm}$ & $\mathrm{p}$ & $1 \mathrm{a}, \mathrm{cm}$ & $\mathrm{p}$ \\
\hline $\mathrm{df}=2$ & \multicolumn{2}{|c|}{$F=2,9850 ; p=0,0536$} & \multicolumn{2}{|c|}{$F=1,1248 ; p=0,3284$} & \multicolumn{2}{|c|}{$F=17,1335 ; p<0,0001$} & \multicolumn{2}{|c|}{$F=8,3088 ; p=0,0004$} \\
\hline M1-M2 & $-0,06$ & 0,8098 & $-0,13$ & 0,4784 & $-0,52$ & 0,0017 & $-0,18$ & 0,2406 \\
\hline M1-M3 & $-0,23$ & 0,0643 & $-0,15$ & 0,3961 & $-0,82$ & $<0,0001$ & $-0,44$ & 0,0004 \\
\hline M2-M3 & $-0,17$ & 0,2333 & $-0,02$ & 0,9891 & $-0,30$ & 0,1049 & $-0,26$ & 0,0646 \\
\hline
\end{tabular}


Tablica 11. Prosječne razlike promjera na obilježenoj visini (2a) između mjeritelja (u $\mathrm{cm})$, rezultati ANOVA-e ponovljenih mjerenja (F i p), te post hoc testa između pojedinih mjeritelja (p vrijednost)

Table 11. Average differences of diameters on marked breast height (2a) between measurers (in $\mathrm{cm}$ ), results of ANOVA with repeated measurements ( $F$ and $p)$, and post hoc test between measurers ( $p$ value)

\begin{tabular}{|c|c|c|c|c|c|c|c|c|}
\hline \multirow{2}{*}{$\begin{array}{l}\text { Mjeritelj } \\
\text { Measurer }\end{array}$} & \multicolumn{2}{|c|}{$\begin{array}{c}\text { Hrast lužnjak } \\
\text { Pedunculate oak }\end{array}$} & \multicolumn{2}{|c|}{$\begin{array}{c}\text { Obični grab } \\
\text { Common hornbeam }\end{array}$} & \multicolumn{2}{|c|}{$\begin{array}{l}\text { Obična jela } \\
\text { Silver fir }\end{array}$} & \multicolumn{2}{|c|}{$\begin{array}{l}\text { Obična bukva } \\
\text { Common beech }\end{array}$} \\
\hline & $2 \mathrm{a}, \mathrm{cm}$ & $\mathrm{p}$ & $2 \mathrm{a}, \mathrm{cm}$ & $\mathrm{p}$ & $2 \mathrm{a}, \mathrm{cm}$ & $\mathrm{p}$ & $2 \mathrm{a}, \mathrm{cm}$ & $p$ \\
\hline$d f=2$ & \multicolumn{2}{|c|}{$F=24,0370 ; p<0,0001$} & \multicolumn{2}{|c|}{$F=1,7725 ; p=0,1747$} & \multicolumn{2}{|c|}{$F=4,3593 ; p<0,0144$} & \multicolumn{2}{|c|}{$F=8,3042 ; p=0,0004$} \\
\hline M1-M2 & 0,05 & 0,7581 & $-0,11$ & 0,3164 & 0,07 & 0,6841 & 0,06 & 0,4985 \\
\hline M1-M3 & $-0,38$ & $<0,0001$ & $-0,13$ & 0,2328 & $-0,15$ & 0,1371 & $-0,14$ & 0,0227 \\
\hline M2-M3 & $-0,43$ & $<0,0001$ & $-0,01$ & 0,9814 & $-0,22$ & 0,0177 & $-0,20$ & 0,0006 \\
\hline
\end{tabular}
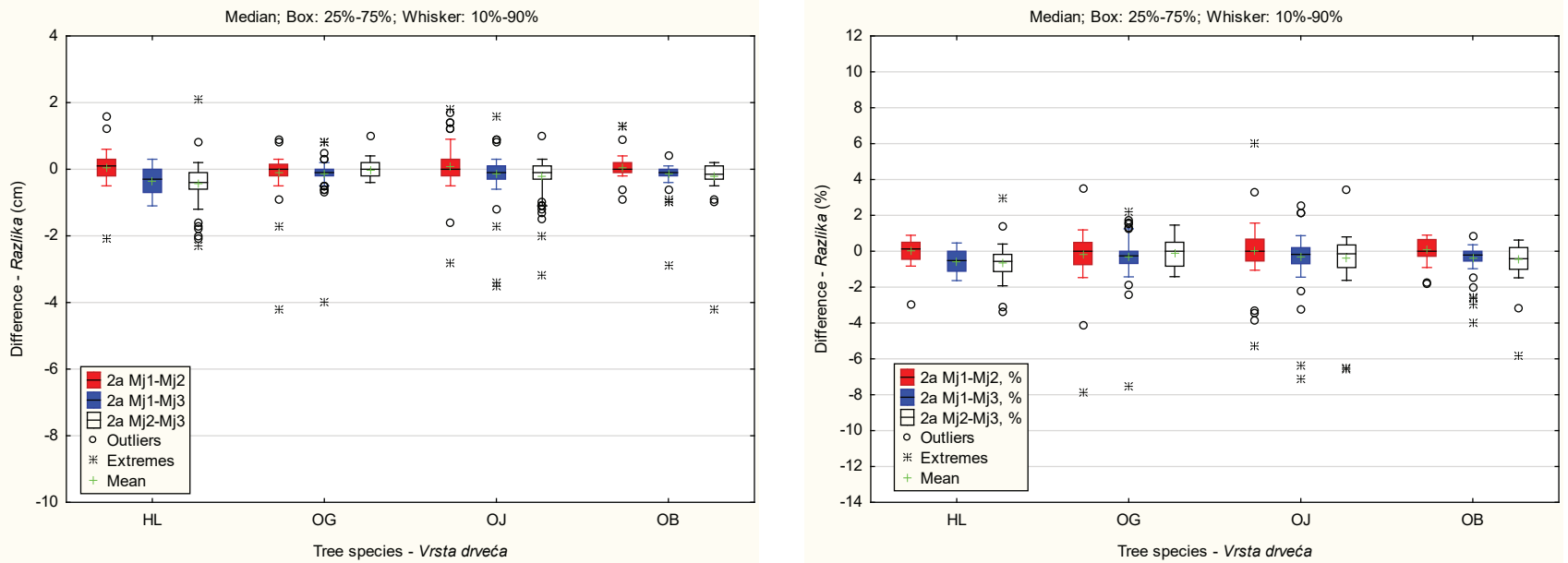

Slika 6. Razlike promjera na obilježenoj visini (2a) između mjeritelja, za hrast lužnjak (HL), obični grab (OG), običnu jelu (OJ) te običnu bukvu (OB); u cm (slika lijevo) te u \% (slika desno)

Figure 6. Differences in diameters on marked breast height (2a) between measurers, for pedunculate oak (HL), common hornbeam (OG), silver fir (OJ) and European beech (OB): in cm (figure left) and in \% (figure right)

Table 12. Average differences of crosswise diameters at marked breast height (2b) between measurers (in cm), results of ANOVA with repeated measurements ( $F$ and $p$ ), and post hoc test between measurers ( $p$ value)

Tablica 12. Prosječne razlike unakrsnih promjera na obilježenoj visini (2b) između mjeritelja (u cm), rezultati ANOVA-e ponovljenih mjerenja (F i p), te post hoc testa između pojedinih mjeritelja (p vrijednost)

\begin{tabular}{|c|c|c|c|c|c|c|c|c|}
\hline \multirow{2}{*}{$\begin{array}{l}\text { Mjeritelj } \\
\text { Measurer }\end{array}$} & \multicolumn{2}{|c|}{$\begin{array}{c}\text { Hrast lužnjak } \\
\text { Pedunculate oak }\end{array}$} & \multicolumn{2}{|c|}{$\begin{array}{c}\text { Obični grab } \\
\text { Common hornbeam }\end{array}$} & \multicolumn{2}{|c|}{$\begin{array}{l}\text { Obična jela } \\
\text { Silver fir }\end{array}$} & \multicolumn{2}{|c|}{$\begin{array}{l}\text { Obična bukva } \\
\text { Common beech }\end{array}$} \\
\hline & $2 \mathrm{~b}, \mathrm{~cm}$ & $\mathrm{p}$ & $2 \mathrm{~b}, \mathrm{~cm}$ & $\mathrm{p}$ & $2 \mathrm{~b}, \mathrm{~cm}$ & $\mathrm{p}$ & $2 \mathrm{~b}, \mathrm{~cm}$ & $\mathrm{p}$ \\
\hline$d f=2$ & \multicolumn{2}{|c|}{$F=0,0040 ; p=0,9961$} & \multicolumn{2}{|c|}{$F=0,6846 ; p=0,5064$} & \multicolumn{2}{|c|}{$F=0,6616 ; p=0,5175$} & \multicolumn{2}{|c|}{$F=0,0672 ; p=0,9351$} \\
\hline M1-M2 & 0,01 & 0,9975 & 0,10 & 0,5497 & 0,01 & 0,9899 & 0,06 & 0,9362 \\
\hline M1-M3 & 0,01 & 0,9966 & 0,02 & 0,9810 & $-0,08$ & 0,6573 & 0,03 & 0,9752 \\
\hline M2-M3 & 0,00 & 0,9999 & $-0,08$ & 0,6673 & $-0,09$ & 0,5715 & $-0,03$ & 0,9904 \\
\hline
\end{tabular}

Iz Tablice 11 vidljivo je da su razlike između mjeritelja kod obilježene prsne visine (2a), veće te većim dijelom statistički značajne između mjeritelja 3 i ostala dva mjeritelja (osim kod graba), gdje je mjeritelj 3 u prosjeku mjerio veće promjere. Veći dio razlika promjera između mjeritelja nalazi se u rasponu $\pm 1 \mathrm{~cm}$ odnosno $1 \%$. U ekstremnim slučajevima razlike su i do $4,5 \mathrm{~cm}$ odnosno $8 \%$ (Slika 6 ).
Iz Tablice 12 vidljivo je da su razlike između mjeritelja kod obilježene prsne visine, unakrsnog promjera (2b), između mjeritelja 3 i ostala dva mjeritelja male te nisu statistički značajne. Veći dio razlika promjera između mjeritelja nalazi se u rasponu $\pm 0,5 \mathrm{~cm}$ odnosno $1 \%$. U ekstremnim slučajevima razlike su (kod bukve) i do $12 \mathrm{~cm}$ odnosno $18 \%$ (Slika 7). 

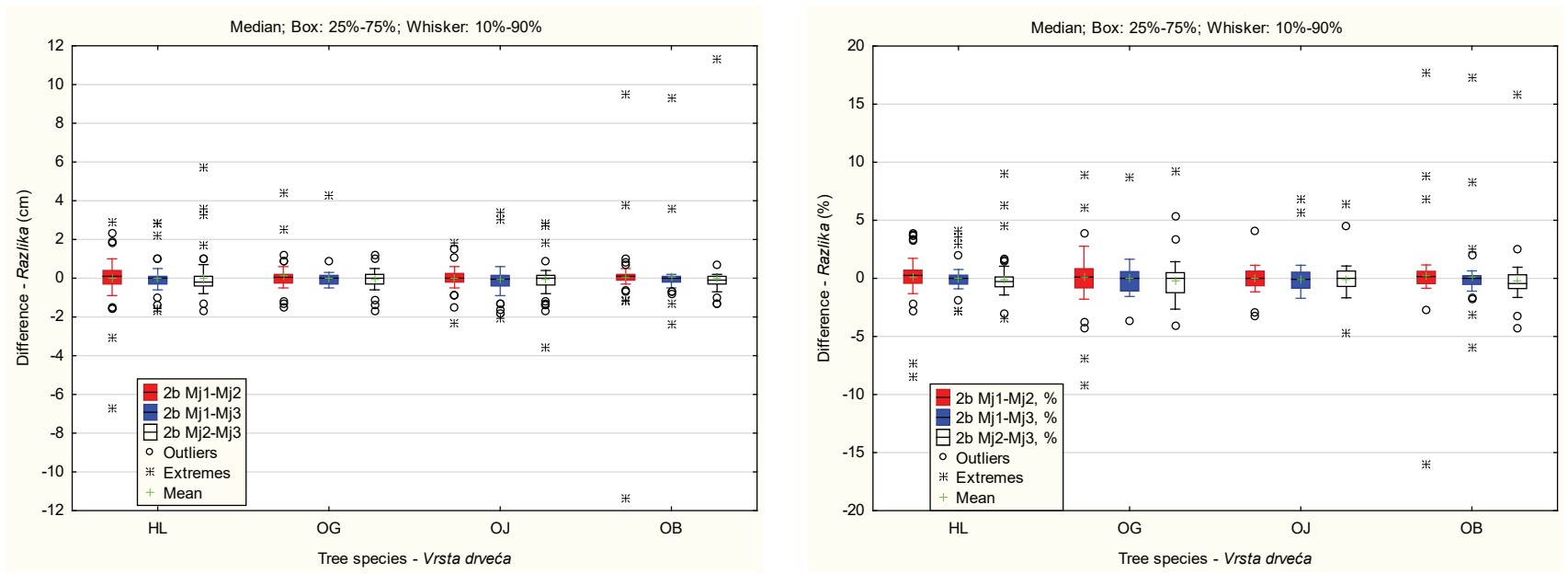

Slika 7. Razlike unakrsnih promjera na obilježenoj visini (2b) između mjeritelja, za hrast lužnjak (HL), obični grab (OG), običnu jelu (OJ) te običnu bukvu (OB); u cm (slika lijevo) te u \% (slika desno)

Figure 7. Differences in crosswise diameters at marked breast height (2b) between measurers, for Pedunculate oak (HL), Common hornbeam (OG), Silver fir (OJ) and Common beech (OB): in cm (figure left) and in \% (figure right)

\section{RASPRAVA}

\section{DISCUSSION}

Izmjereni promjeri stabala, bilo da ih mjerimo s milimetarskom preciznošću ili ih grupiramo u debljinske stupnjeve, osnova su za obračun volumena, kako pojedinačnih stabala tako i sastojine. Stoga i odstupanja/pogreške prilikom izmjere promjera imaju posljedice na procjenu volumena. Upravo zbog važnosti izmjerenih promjera, svaka je izmjera podložna kontroli, a u nekim se slučajevima i propisuju dopuštena odstupanja u izmjeri. Omule (1980) napominje da je kod British Columbia Forest Service dozvoljena pogreška od $1 \%$ za prsni promjer, a Melson i dr. (2002) navode dozvoljene pogreške pri izmjeri promjera do približno $\pm 0,25 \mathrm{~cm}$ za stabla promjera 12,5 do $50 \mathrm{~cm}, \pm 0,5 \mathrm{~cm}$ za stabla promjera $50-100$ $\mathrm{cm}$ te $0,75 \mathrm{~cm}$ za stabla promjera $100-150 \mathrm{~cm}$.

U svakom slučaju na mjeriteljima je da izmjeru provedu što kvalitetnije odnosno po pravilima struke. Na taj način eliminirat će se one pogreške koje su posljedica nesavjesne izmjere.

\section{Razlike položaja promjerke pri izmjeri - Differences in caliper position during measurement}

Kao što je iz rezultata vidljivo razlika u izmjerenom promjeru može biti posljedica eliptičnosti stabla (Tablice 2 i 3 i Slika 1). Upravo stoga je u provedbi Nacionalne inventure šuma RH propisano da se mjesto izmjere trajno obilježi (Čavlović i Božić, 2008), kako bi se pri kontroli izmjere moglo procijeniti koliko dobro je izmjera provedena, te da se iz izmjere ponovljene za nekoliko godina može točnije izračunati debljinski prirast stabla.

Iz rezultata prikazanih u Tablicama $2 \mathrm{i} 3$ vidljivo je da postoji razlika u srednjim vrijednostima unakrsnih promjera, koja je za grab i bukvu veća i statistički značajna. Tako je prsni promjer grabovih stabala izmjeren u pravcu SI-JZ veći za $1-1,5 \mathrm{~cm}$ od promjera izmjerenog u pravcu SZ-JI. Kod bukve je srednji promjer mjeren u slojnici za 1,6-1,8 cm manji od unakrsnog promjera, što je u skladu s Van Laar i Akça (2007). Niže razlike kod graba su vjerojatno posljedica značajno manjeg srednjeg promjera uzorka stabala graba $(30,49 \mathrm{~cm}) \mathrm{u}$ odnosu na uzorak stabala bukve $(37,46 \mathrm{~cm})$, odnosno raspona promjera stabala u uzorku (Tablica 1).

Na razini pojedinačnih stabala svih vrsta drveća razlike promjera se kreću i do $5 \mathrm{~cm}$ odnosno $15 \%$, a u ekstremnim slučajevima i $15 \mathrm{~cm}$ odnosno 30-ak \% (Slika 1). Iz Slike 2 vidljivo je da je većina stabala manje ili više eliptična, a ako usporedimo srednje apsolutno odstupanje (Slika 2) s prosječnim (Slika 1) jasno je da je kod pojedinih stabla bukve promjer u slojnici veći od njegovog unakrsnog promjera. Iako su poprečni presjeci debla bukve više ili manje slični krugu (Ugrenović, 1950), isti autor tvrdi da nagib terena može utjecati na eliptičnost, što je potvrđeno i ovim rezultatima. Imajući ove rezultate u vidu, izmjeru za razinu uzorka svakako je bolje (ako se mjeri samo jedan promjer) provesti mijenjanjem kuta izmjere, odnosno zakretanjem ravnala (ili krakova) promjerke prema središtu plohe, odnosno po principu zakretanja promjerke naizmjenično pod kutem od $45^{\circ}$ na jednu odnosno drugu stranu u odnosu na pravac kretanja (definirani azimut), kod izmjera na primjernim prugama, doznake (odabir te evidentiranje stabala za sječu) ili pak izmjere promjera pri izmjeri visina stabala.

Povećanjem promjera stabala razlika između dva unakrsna promjera se povećava (Slika 3), što je u skladu s istraživanjima Prodana (1965) i Melsona i dr. (2002).

Johnson i Haag (1985) napominju da postavljanje promjerke na stablo bez obilježbe prsne visine može biti veliki izvor po- 
greške, a Omule (1980) pogreške pri izmjeri promjera većinom adresira na pogreške pri određivanju prsne visine. Te su pogreške potvrđene i u ovom istraživanju, pri čemu je promjer na neobilježenoj visini u prosjeku manji od promjera na obilježenoj prsnoj visini (Tablica 4) za sve vrste drveća te kod svih mjeritelja. U našem istraživanju najveću i statistički značajnu razliku (osim kod graba) između promjera na samoodređenoj i obilježenoj prsnoj visini imao je mjeritelj 1. Mjeritelj 2, s druge strane ima najmanju te statistički neznačajnu razliku (Tablica 4). S obzirom da su oba navedena mjeritelja podjednako visoka (1,75 odnosno 1,73 $\mathrm{m})$ te da im je prsna visina oko $1,30 \mathrm{~m}$ ta je razlika kod mjeritelja 1 neočekivana, a može biti posljedica previsokog položaja ili prejakog stiska promjerke pri izmjeri.

Svakako treba zamijetiti (Slika 1) da je razlika između promjera na samoodređenoj i obilježenoj prsnoj visini (vezano uz pad promjera) puno manja nego razlika dvaju unakrsnih promjera (vezano uz eliptičnost poprečnog presjeka). Teško je utvrditi jesu li razlike između izmjere na samoodređenoj i obilježenoj prsnoj visini posljedica izmjere na različitoj visini ili nepostavljanja promjerke pri samoodređivanju prsne visine pod istim kutom (u odnosu na pravac kretanja odnosno slojnicu) u odnosu na izmjeru na obilježenoj prsnoj visini.

Promatrajući deblo lako se uočava pad njegovog promjera s povećanjem visine. Uslijed navedenog, rezultati razlika promjera mjerenih $10 \mathrm{~cm}$ ispod i iznad prsne visine, a prikazani u Tablicama 5 i 6 su očekivani. Prosječne razlike između izmjere na 1,20 i $1,30 \mathrm{~m}$ su pozitivne (od $0,23 \mathrm{~cm}$ za bukvu do $0,80 \mathrm{~cm}$ za hrast lužnjak), a negativne između 1,40 i $1,30 \mathrm{~m}$ (od - $0,21 \mathrm{~cm}$ kod graba do $-0,60 \mathrm{~cm}$ kod lužnjaka), pri čemu su ove zadnje u apsolutnom iznosu (osim kod bukve) radi izraženijeg pada promjera ispod prsne visine, očekivano manje. Na nagnutim terenima kada se izmjera provodi uz zakretanje ravnala prema središtu plohe, ispravno je prići stablu sa pribrežne strane, postaviti promjerku na prsnu visinu, te je zakrenuti da ravnalo promjerke bude okrenuto prema središtu plohe (Čavlović i Božić, 2008). Poneki mjeritelji stablu prilaze tako da ravnalo odmah zakreću prema središtu plohe, pri čemu promjerku postavljaju na „prsnu visinu“ koja nije s pribrežne strane te tako mjere promjer na visini nižoj od prsne, što rezultira precjenjivanjem izmjerenih promjera. Iz Slike 4 vidljivo je da pojedina stabla imaju veći promjer na prsnoj visini nego na visini $10 \mathrm{~cm}$ ispod nje, odnosno manji u odnosu na promjer mjeren $10 \mathrm{~cm}$ iznad prsne visine, što ukazuje na nepravilnosti pri rastu, u odnosu na očekivani rast stabla, a posebno je izraženo kod graba, kod kojeg je izražen nepravilni poprečni presjek vidljiv kao usukanost žice te užlijebljenost debla (Ugrenović, 1950).

Izmjerom promjera tako da ravnalo ne dotiče stablo (,izmjera krakovima“) uz normalni pritisak na pomični krak promjerke u prosjeku se dobivaju nešto niži promjeri (od
$0,13 \mathrm{~cm}$ kod graba do $0,26 \mathrm{~cm}$ kod hrasta) te su navedene razlike statistički značajne (Tablica 7). Uz jači pritisak razlike se očekivano povećavaju, za oko $0,4 \mathrm{~cm}$ kod bukve do gotovo $1 \mathrm{~cm}$ kod hrasta lužnjaka (Tablice 7 i 8). Razlika se povećava sa povećanjem promjera stabla, posebno kod jačeg pritiska na pomični krak, čemu bi uzrok mogao biti što krakovi promjerke kod izmjere debljih stabala ponekad nisu bili postavljeni tako da se njima obuhvati čitav promjer stabla. U svrhu izbjegavanja pogrešaka vezano uz jači pritisak na krakove promjerke Kennel (1959 - prema Loetsch i dr. (1973)) napominje da pritisak ne treba prelaziti $12 \mathrm{~kg}$. Prejaki pritisak dovodi do pogreške u temeljnici do 3,5\% (Tiren (1929) - prema Loetsch i dr. (1973)). Nadalje, Loetsch i dr. (1973) napominju da je pogreška negativna te da ovisi o mjeritelju kao i otpornosti kore na kompresiju.

U praksi je uočeno da mjeritelji, osobito oni nižeg rasta, radi lakšeg očitanja na ravnalu često zakreću krakove promjerke prema gore. Kao što se iz Tablice 9 vidi ta je pogreška negativna, a prosječno iznosi od $-0,24 \mathrm{~cm}$ kod graba do $-0,79 \mathrm{~cm}$ kod hrasta.

Razlike između promjera izmjerenih na prsnoj visini i promjera na visini od $1,40 \mathrm{~m}$ slične su razlikama između promjera na prsnoj visini i promjera kada je promjerka postavljena na prsnu visinu, ali s krakovima zakretanim prema gore (Tablice 6 i 9 te Slika 4). To je i očekivano jer se u drugom slučaju krakovi na mjestu gdje dotiču stablo nalaze iznad $1,30 \mathrm{~m}$.

\section{Razlike između mjeritelja - Differences between measurers}

Razlike između izmjerenih promjera različitih mjeritelja na samoodređenoj prsnoj visini (Tablica 10) je vezana uz mjeritelja 1, koji je kao što je ranije prikazano imao najveću i statistički značajnu razliku između izmjere na samoodređenoj i obilježenoj prsnoj visini (Tablica 4). Obilježavanje točke izmjere većinom dovodi do smanjenja razlika između mjeritelja (usporedi Tablice 10 i 11 te Slike 5 i 6) što je u skladu s sličnim istraživanjima (npr. Johnson i Haag 1985, i Omule 1980).

Razliku između mjeritelja pri izmjeri na obilježenoj prsnoj visini prikazanu u Tablici 11, gdje je statistički značajna razlika većim dijelom vezana uz mjeritelja 3 , teže je obrazložiti jer je ravnalo promjerke kod svih mjeritelja postavljano na točku obilježbe. Obzirom da je prsna visina obilježena sprejom, pri čemu je promjer točke 2-3 cm, moguće je da se kod prislanjanja ravnala na obilježenu točku ravnalo ponekad prislonilo na sredinu ili rubove točke (a ne uz gornji rub kako propisuju Husch i dr. (2003)). Stoga bi dobivena razlika između mjeritelja mogla biti posljedica ranije spomenute eliptičnosti stabla (Tablice 2 i 3). Međutim, kako se vidi iz Tablice 12, kod unakrsnih promjera razlika je manja te nigdje nije statistički značajna što tu mogućnost stavlja 
pod znak pitanja. S obzirom da je mjeritelj 3 pri izmjeri obilježenih prsnih promjera dobivao u prosjeku veće vrijednosti od ostale dvojice, postoji mogućnost da je pritisak na pomični krak mjeritelja 1 i 2 bio nešto veći, i to samo kod izmjere na obilježenoj točki (izmjera 2a). To je moguće objasniti činjenicom da se pri mjerenju unakrsnih promjera promjerka u odnosu na izmjeru na obilježenoj visini zakreće za $90^{\circ}$, uz minimalno zakretanje mjeritelja (iskorak u stranu) radi osiguranja njegove stabilnosti, pri čemu je pritisak na pomični krak vjerojatno manjeg intenziteta, te su stoga pri izmjeri unakrsnih promjera razlike između mjeritelja manje te nisu statistički značajne.

Maksimalne razlike između mjeritelja kod izmjere obilježenih promjera (Slika 6) odnosno unakrsnih promjera (Slika 7) iznose do 4,5 odnosno $12 \mathrm{~cm}$. Maksimalna razlika pri kontrolnoj izmjeri pri provođenju prve nacionalne inventure šuma RH (Čavlović, 2010) iznosila je $14 \mathrm{~cm}$. Čavlović napominje da ta razlika upućuje na grubu pogrešku, a takvima možemo smatrati i ekstremne razlike prikazane u rezultatima. Veći dio odstupanja kontrolne izmjere u prvoj nacionalnoj inventuri nalazi se u rasponu $\pm 1,5 \mathrm{~cm}$ što je u skladu s rezultatima našeg istraživanja (vidjeti Slike 6 i 7).

Pranjić i Lukić (1997) napominju da najčešće pogreške pri mjerenju promjerkom nastaju kada pomični krak nije okomit na ravnalo. S obzirom da smo promjerke kalibrirali prije izmjere, ova vrsta pogreške je izbjegnuta osim u slučaju jačeg pritiska na krakove promjerke.

Izmjeru za ova istraživanja proveli su stručnjaci s višegodišnjim iskustvom u izmjerama. O učincima treninga na kvalitetu izmjere prsnog promjera pisali su Kitahara i dr. (2010), te Elzinga i dr. (2005) koji napominju da se treningom pogreške mogu smanjiti, ali ne i eliminirati. Omule (1980) piše da su pogreške pri izmjeri manje ako su mjeritelji dobro utrenirani i iskusni, a šumski i vremenski uvjeti povoljni.

Izmjere za ova istraživanja, s obzirom na cilj istraživanja, provedena su vrlo savjesno. U otežanim okolnostima rada pod vremenskim pritiskom, očekuju se daleko veće pogreške (Loetsch i dr., 1973) čak i uz poštivanje svih procedura izmjere. Kao što je prethodno navedeno, uz sve provjere pojavila se i jedna ekstremna pogreška pri prepisivanju rezultata, te vrlo vjerojatno dva „ekstremna“ kriva upisa (ili očitanja) unakrsnog promjera. Spomenute pogreške mogu se eliminirati korištenjem promjerki u kojima se rezultati izmjere direktno pohranjuju na „računalo“ (npr. promjerke tipa Digitech Professional II).

Treba imati u vidu da pogreške pri izmjeri promjera pojedinačnih stabala utječu na raspodjelu broja stabala po debljinskim stupnjevima te obračun volumena sastojine, što bi svakako valjalo istražiti.

\section{ZAKLJUČCI}

\section{CONCLUSIONS}

Činjenicu da unakrsni promjeri stabala mogu biti jako različiti svakako treba u praksi imati u vidu pri kontroli izmjere, osobito ako stablima nije obilježeno mjesto izmjere ili poznato središte plohe i procedura izmjere (izmjera u slojnici ili zakretanje ravnala prema središtu plohe), jer se izmjereni promjeri istog stabla mogu značajno razlikovati. Rezultati na razini uzorka ukazuju da kod graba i bukve postoji statistički značajna razlika unakrsnih promjera, kao posljedica utjecaja strane svijeta odnosno nagiba terena. Ove bi razlike (za navedene, ali i druge vrste drveća) bilo dobro provjeriti na većem uzorku, prikupljenog na širem prostoru, a u sklopu redovnih izmjera za izradu osnova odnosno programa gospodarenja ili pak doznake stabala. $\mathrm{Uz}$ zakretanje ravnala promjerke prema središtu plohe, razlike utjecane stranom svijeta i nagibom terena bi se na razini uzorka vjerojatno poništile. Kod stabala koja se doznačuju, oznaku bi trebalo postaviti na prsnu visinu s gornje strane stabla (na nagibu), kako je definirano člankom 4. Pravilnika o doznaci stabala (NN 17/2015), te tako smanjila pogreška pri izmjeri promjera na razini pojedinačnog stabla. Predlažemo da ako se potvrdi utjecaj strane svijeta odnosno nagiba terena na izmjereni promjer na razini uzorka, radi eliminiranja tog utjecaja kod svakog drugog stabla promjerka zakrene za $45^{\circ}$ na jednu odnosno drugu stranu u odnosu na slojnicu ili definirani pravac kretanja, ako se radi o ravnom terenu. Ako se navedeni prijedlog prihvati trebalo bi sukladno tome izmijeniti spomenuti Pravilnik.

Rezultati istraživanja ukazuju na važnost poštivanja procedura izmjere da bi se izbjegle pogreške pri izmjeri promjera. Isto tako bitno je da se rezultati izmjere točno prepišu s terenskih obrazaca u računalo (ako se na terenu upisuju u papirni obrazac). Pogreške pri izmjeri, upisu te prepisivanju rezultata izmjere, u konačnici imaju utjecaj i na izračun volumena pojedinačnih stabala odnosno raspodjelu broja stabala po debljinskim stupnjevima i volumen sastojine.

Za primjenu u šumarskoj praksi bilo bi poželjno iskazati kolika smije biti pogreška pri izmjeri promjera stabala. To nije moguće jednoznačno odrediti te bi takav propis trebao ovisiti o svrsi izmjere te željama nalogodavca za koga se izmjera provodi. Rezultati ovog istraživanja mogu u tome pridonijeti s time da bi osim same svrhe (uređajna izmjera, doznaka, ...) bilo potrebno uzeti u obzir prirodna svojstva mjerenih sastojina, uvjete rada i vještinu radnika.

\section{LITERATURA}

\section{REFERENCES}

- Avery, T.E., H.E. Burkhart, 1983: Forest measurements, McGraw-Hill Publishing, 331 str., New York

- Banković, S., D. Pantić, 2006: Dendrometrija, Šumarski fakultet Univerziteta, 556 str., Beograd 
- Čavlović, J., Božić, M., 2008: Nacionalna inventura šuma u Hrvatskoj - Metode terenskog prikupljanja podataka, Šumarski fakultet Sveučilišta u Zagrebu, 146 str., Zagreb

- Čavlović, J., 2010: Prva nacionalna inventura šuma Republike Hrvatske, Šumarski fakultet Sveučilišta u Zagrebu, 300 str., Zagreb

- Elzinga, C., R.C. Shearer, G. Elzinga, 2005: Observer variation in tree diameter measurements, Western Journal of Applied Forestry, Vol. 20. (2): 134-137., Bethesda

- Husch, B., T.W. Beers, J.A. Kershaw Jr., 2003: Forestmensuration (4th ed.), John Wiley\&Sons, 443 str., New York

- Johnson, J. E., Haag, C. L., 1985: Reliability of height and diameter remeasurements on Red pine (Pinus resinosa Ait.) seedlings, Tree Planter's Notes, Vol. 36, (2): 27-29., Washington, D.C.

- Keller, M., 2005: Schweizerisches Landesforstinventar, Forschungsanstalt für Wald, Schnee und Landschaft, 393 str., Birmensdorf

- Kitahara, F., N. Mizoue, S.Yoshida, 2010: Effects of training for inexperienced surveyors on data quality of tree diameter and height measurements. Silva Fennica 44(4): 657-667, Helsinki

- Laar, A. van, A. Akça, 2007: Forest mensuration, Springer Science \& Business Media, 383 str., Heidelberg
- Loetsch, F., F. Zöhrer, K.E. Haller, 1973: Forest Inventory, BLV Verlagsgesellchaft, 436 str., Munich

- Melson, S., D. Azuma., J.S. Fried, 2002: A first look at measurement error on FIA plots using blind plots in the Pacific Northwest, U: McRoberts, R.E., G.A. Reams, P.C. Van Deusen, J.W. Moser, (ur.), Proceedings of the Third Annual Forest Inventory and Analysis Symposium, Gen. Tech. Rep. NC-230. St. Paul, MN: U.S. Department of Agriculture, Forest Service, North Central Research Station, str. 11-20, Traverse City

- Omule, S.A.Y., 1980: Personal bias in forest measurements, The Forestry Chronicle, Vol. 56. 222-224., Vancouver, B.C.

- Pranjić, A., N. Lukić, 1997: Izmjera šuma, Šumarski fakultet Sveučilišta u Zagrebu, 405 str., Zagreb

- Pravilnik o doznaci stabala. Narodne novine (17/2015), Službeni list Republike Hrvatske

- Prodan, M., 1965: Holzmesslehre, J.D. Sauerlander's Verlag, 659 str., Frankfurt

- TIBCO Software Inc., 2018: Statistica (data analysis software system), version 13. http://tibco.com.

- Ugrenović, A., 1950: Tehnologija drveta, Nakladni zavod Hrvatske, 502 str., Zagreb

\section{SUMIMARY}

A tree diameter at breast height ( $\mathrm{dbh}$ ) is a basic variable measured in forest inventory. Generally, it is measured with calipers whose arms have to be perpendicular to the beam. Therefore, caliper has to be rectified before measurement. Measurement should be performed in the way that caliper itself is perpendicular to the tree stem with arms and beam touching the tree without applying too much pressure to caliper arms. Measurer mistakes and failing to follow standard measurement procedures lead to errors that reflect in all inventory results (basal area, stand volume). Experience gathered while working with students and colleagues in practice, showed that measurement procedures sometimes significantly depart from required. Therefore, the aim of this research was to quantify and analyze known and observed dbh measurement errors.

For that purpose two sites in Zagreb Training and Forest research center were selected: one site in area of lowland oak and hornbeam forest stand and another in mountain area with mixed fir and beech forest. Total 282 trees (74 Pedunculate oak, 56 Common hornbeam, 76 Silver fir and 76 Common beech) in wide diameter range were measured. (Table 1). All selected trees were marked with a number before measurement.

On both research plots three measurers performed following diameter measurements using Haglof Mantax caliper: crosswise diameters at self-estimated breast height with ( $1 \mathrm{a}, 1 \mathrm{~b})$, crosswise diameters at marked breast height (2a, 2b), $10 \mathrm{~cm}$ above (3a) and $10 \mathrm{~cm}$ under the marked breast height (3b), at marked breast height point with caliper beam held apart from tree and normal pressure on the caliper arms (4a) and higher pressure on the caliper arms (4b) and caliper beam on marked point with caliper tips facing up (5a). Measurement group consisted of two measurers. One measurer preformed measurement and other was writing the data. Since measurers height can affect the placement of the calipers on the tree, so position of breast height of $1,3 \mathrm{~m}$ was determined using measuring tape before beginning of measurement for each measurer. Marking of breast height point on the tree was made after measurement with self-estimated breast height. Collected data were analyzed using t-test and ANOVA with 0,05 significance level.

Results show that average differences between two crosswise diameter measurements at self estimated breast height are statistically significant for hornbeam (average difference $1 \mathrm{~cm}$ ) and beech (average $1,7 \mathrm{~cm}$ ). Fir and oak had less differences (up to $0,7 \mathrm{~cm}$ ) that were not proven statistically significant. (Table 2).

At marked breast height differences of crosswise measurements are as well statistically significant for hornbeam and beech. (Table 3). Comparison between average diameter difference at self-estimated 
and marked breast height show statistically significant difference for oak and beech. Negative average values for all measured species suggest that measurers usually slightly overestimated breast height (Table 4). According to Figure 1 it is visible that crosswise diameter differences are mostly within $\pm 2-3$ $\mathrm{cm}$ (50\% difference). Certain trees show difference up to $15 \mathrm{~cm}$ in crosswise diameters. At the same time, diameter differences between self-estimated and marked breast height are smaller than crosswise diameter difference. Figure 2 shows that there is almost no trees which are not elliptical with fir having the smallest values.

Diameter measured $10 \mathrm{~cm}$ under marked breast height expectedly resulted in statistically significant higher values for all tree species with $0,49 \mathrm{~cm}$ on average (Figure 4), and diameters measured $10 \mathrm{~cm}$ above marked breast height resulted in lower values being statistically significant for oak, beech and fir (Figure 5). The biggest difference is for oak trees.

When caliper beam was held apart from tree and normal pressure on caliper arms applied, results were $-0,12$ to $-0,26 \mathrm{~cm}$ lower and statistically significant compared to readings at correct position (caliper beam on the tree). The similar results were achieved with stronger pressure on the arms but with higher negative values, as expected.

Measurement with arm tips facing up resulted with statistically significant lower average diameter reading for all measured tree species (Table 9). Moreover, Figure 4 shows that in comparison to diameter measured on marked breast height readings on the caliper scale were in range between $-1,5$ to $+0,5 \mathrm{~cm}$ with extremes ranging from -4 to $+2 \mathrm{~cm}$ respectively.

Differences between measurers were observed on self-estimated breast height and for crosswise diameters on marked breast height. Table 10 and Figure 5 show that diameter differences between measurer 1 and other two measurers have proven to be statistically significant for self-estimated breast height of fir and beech trees (forest stand on sloping ground) where measurer 1 in average measured smaller diameters. Further, with diameters measured on marked breast height, differences were significant between measurer 3 and other two measurers in the way that measurer 3 on average measured larger diameters (Table 11 and Figure 6)

Diameter measurement is the basis for volume estimation of individual trees and stand as well. Therefore, measurement errors have impact on volume estimation, so measurement is subjected to control and sometimes allowable measurement departures are prescribed. Omule (1980) mentions that in Columbia Forest Service allowable errors of $1 \%$ for $\mathrm{dbh}$ is allowed and Melson et al. (2002) states that allowable dbh errors are $\pm 0,25 \mathrm{~cm}$ for trees from 12,5 to $50 \mathrm{~cm}, \pm 0,5 \mathrm{~cm}$ for trees from $50-100 \mathrm{~cm}$ and $0,75 \mathrm{~cm}$ for treesfrom $100-150 \mathrm{~cm}$ dbh. Measurer responsibility is to perform the measurement according to the rules and with highest possible precision.

As the results show, differences in diameters can be a result of eliptical trees (Table 2, 3 and Figure 1). On tree level, differences sometimes reach $30 \%$ of tree diameter (Figure 1). With increase of tree diameter the difference between two crosswise diameters increases as well (Figure 3). Also, measurement under or above actual beast height results in statistically significant positive or negative diameter values.

Results based on measured sample trees show that hornbeam and beech breast height measurement gives a significant difference in crosswise diameters as a result of sloping ground and geographic orientation. Turning the caliper beam towards the plot center can cancel out these measurement errors assuming an adequate sample size. Furthermore, on trees that are to be cut, the breast height should be marked (on the upper side of the slope). In this way measurement error for a single tree level would be reduced. Finally, this research points out the importance of following correct procedures while tree diameter measurement in order to minimize measurement errors which can affect accuracy of measured data.

KEY WORDS: diameter at breast height, measurement errors, bias, forest inventory 